\title{
Numerical Simulation of Tsunami in the Black Sea Caused by the Earthquake on September 12, 1927
}

\author{
A. Yu. Bazykina*, S. Yu. Mikhailichenko, V. V. Fomin \\ Marine Hydrophysical Institute, Russian Academy of Sciences, Sevastopol, Russian Federation \\ *e-mail: aleksa.44.33@gmail.com
}

\begin{abstract}
Within the framework of the nonlinear model of long waves, the numerical simulation of the tsunami evolution in the Black Sea caused by the Yalta earthquake of September 12, 1927 is performed. Two problems on propagation of tsunami waves from the elliptical source are solved: for the whole Black Sea water area and for the local part of the Crimea Southern coast. The calculations for the first numerical experiment are carried out on a 30-second bathymetric grid of the Black Sea. The sea level oscillations for several points on the Crimean and Caucasian coasts are calculated and compared with the available records of the tide gauges. The amplitudes of the model level oscillations in the coastal zone during propagation of tsunami waves are larger than those recorded instrumentally. This fact is related to inaccuracy in modeling the tsunami generation site due to small amount of information on this event. In all the points, except for Yalta, the sea level oscillations did not exceed the height of the tsunami center initial elevation. In Yalta the wave height can attain $2 \mathrm{~m}$, in Evpatoria $-0.2 \mathrm{~m}$, in Sevastopol - 0.4 m, in Feodosia - 0.5 m, in Kerch - 0.4 m, in Novorossiysk - 0.5 m, in Tuapse $0.3 \mathrm{~m}$ and in Batumi $-0.5 \mathrm{~m}$. The second numerical experiment implies calculation of the tsunami evolution followed by the wave run-up on the Crimea Southern coast. The 50-meter bathymetric grid is applied. For 10 points of the Crimea Southern coast, the sea level oscillations occurring during tsunamis are calculated and the amplitude characteristics during the wave run-up are assessed. The coastline in the region of Yalta, Nikita and Gurzuf is the most strongly affected. The height of the tsunami waves' run-up on the coast in Nikita can make up $2 \mathrm{~m}$, and the sea level drop at draining the coast - more than $3 \mathrm{~m}$.
\end{abstract}

Keywords: nonlinear long waves, numerical simulation, tsunami in the Black Sea, Yalta earthquake of September 12, 1927, tsunami hazard of the Black Sea coast.

Acknowledgements: the study is carried out within the framework of the State Order No. 0827-20180004 "Complex Interdisciplinary Investigations of the Oceanologic Processes Conditioning Functioning and Evolution of the Ecosystems in the Black and Azov Sea Coastal Zones" (Coastal research code).

For citation: Bazykina, A.Yu., Mikhailichenko, S.Yu. and Fomin, V.V., 2018. Numerical Simulation of Tsunami in the Black Sea Caused by the Earthquake on September 12, 1927. Physical Oceanography, [e-journal] 25(4), pp. 295-304. doi:10.22449/1573-160X-2018-4-295-304

DOI: 10.22449/1573-160X-2018-4-295-304

(C) 2018, A. Yu. Bazykina, S. Yu. Mikhailichenko, V. V. Fomin

(C) 2018, Physical Oceanography

\section{Introduction}

Due to the rare frequency of tsunamis in the Black Sea and the small amount of natural data, the tsunami hazard of the Black Sea region has not been adequately studied. However, in recent years interest on this problem has been growing, new sources of information have appeared and methods and approaches to identifying events that could cause a tsunami have been improved. If 20 years ago the catalog of the tsunami of the Azov-Black Sea region counted 22 events for 2000 years [1], then currently 50 tsunamigenic events occurred over the last 3000 years are already known [2]. Thus, tsunamis of different intensity can occur in the Black Sea on average 1-2 times per 100 years. 
Information on the Black Sea tsunami comes mainly from observations of the eyewitnesses, described in chronicles and legends. The historical tsunami are known to be destructive. The destructive phenomena with wave heights more than $2 \mathrm{~m}$ were monitored among them. Tsunami occurred along many parts of the Black Sea coast. They were most often caused by local earthquakes: the majority of them - with epicenters in the sea and only some had their epicenters on land. Four phenomena of the 20th century tsunami, being of seismic origin, were recorded by means of mareographs. These are two events caused by the earthquakes of 1927, as well as the events of 1939 and 1966. In [1, 3-8], sea level fluctuations for several points of the Black Sea coast were studied. According to instrumental records, the wave period, the appearance time of the first tsunami wave and the nature of the fluctuations were estimated. Mareographs reproduced tsunami waves having only a few centimeters in height. According to eyewitnesses, in reality, the wave heights were much larger [5], which is due to their amplification during the run-up to the shore.

Considering the fact that currently there is not enough data on the tsunami in the Black Sea, it should be noted that this phenomenon remains, although rare, but quite dangerous for the coast of the considered region. Consequently, it becomes necessary to carry out numerical calculations to determine the possible wave heights in the tsunami propagation in the Black Sea coastal area.

The numerical study of the Black Sea coast tsunami hazard was carried out in [9-13]. The calculations show that propagations of the sea level and horizontal velocities essentially depend on the features of the basin bottom, coast shape, tsunami source location and the earthquake magnitude. The calculations on modeling two tsunamis caused by earthquakes in 1939 and 1966 were performed in [10]. In [14] an analysis of the sea-level fluctuation nature in the propagation of tsunami waves during earthquakes in 1927 based on calculations on a 15-kilometer grid was carried out.

In the present paper, the results of a numerical simulation of the evolution of a tsunami caused by the Yalta earthquake on September 12, 1927 are presented. Unlike [14], the calculations were performed using a more detailed bathymetric grid with a resolution of 30". The evolution of waves from an elliptical tsunami source was studied within the entire Black Sea area. For a number of points on the Crimean and Caucasian coasts the model mareograms were compared with the existing records of mareographs. In particular, the propagation of waves from a tsunami source of the southern Crimean coast shelf, which is most susceptible to destructive effects, was studied. The mareograms for this part of the coast and the maximum sea level elevations and drops during the wave run-up to the coast were analyzed.

\section{Yalta earthquake of September 12, 1927}

The strongest Black Sea earthquake of the 20th century, generated the tsunami waves, occurred on September 12, 1927, $30 \mathrm{~km}$ east of Yalta, in the zone of increased seismic activity of the Black Sea depression [3]. It had a magnitude of 6.5 according to $[3$, p. $484 ; 15$, p. 12$]$ and $6.8 \pm 0.1$ according to the data of [10, p. $6 ; 16$, p. 948; 17, p. 89]. There is no exact information on the extent of the earthquake region, presumably it was 86-100 km [18]. Tsunami waves were recorded by coastal mareographs of the Crimean and Caucasian coasts. The highest 
wave height was instrumentally recorded near the coast of Evpatoria and amounted to $0.5 \mathrm{~m}$ [3]. According to eyewitnesses [17, 18], in many coastal areas of Crimea the tsunami phenomenon caused by the earthquake did not go unnoticed.

For example, in Balaklava Bay at flat calm sea its level fell $1 \mathrm{~m}$ below the average level and then exceeded it by more than $1 \mathrm{~m}$ [18]. The water moved away for a few meters so that small vessels remain on the rocks. Then it rushed to the shore and flooded part of the land [17]. In Sevastopol on September 12, the Maritime Observatory mareograph recorded continuous changes in the water level in the bays during all day. In Evpatoria, the sea was calm, but after the shock the surf appeared. It could be caused by the bottom concussion to the west of the coast. In Yalta, sea level dropped sharply and its fluctuations intensified [17]. In total, several spaced in time earth shocks were recorded, and sea level fluctuations lasted several days.

Thus, the Crimean coast was exposed to the greatest effect of waves appeared as a result of this earthquake. Although tsunami in the Black Sea basin is rare, the catastrophic phenomenon probability, which can cause serious damage to the population and the economy of coastal areas, cannot be disregarded.

\section{Mathematical task setting}

The present study considered the basin with the bottom topography and coastline shape simulating the Black Sea. The calculations used the 30-second bathymetry of the World Ocean (data taken from the General Bathymetric Chart of the Oceans Digital Atlas (URL: https://www.gebco.net/)). It is shown in Fig. 1.

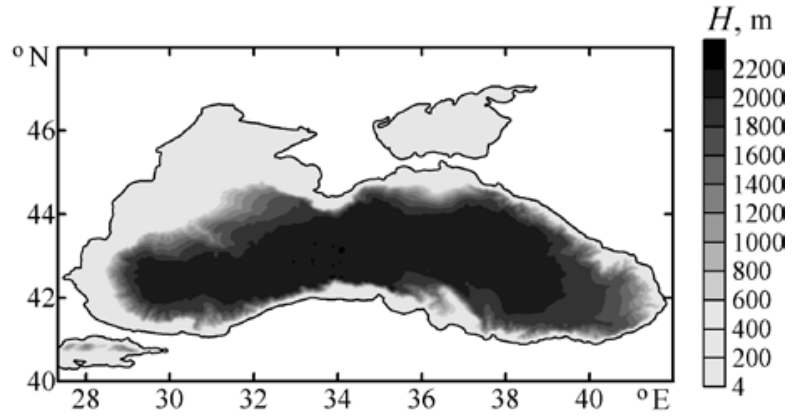

Fig. 1. Distribution of depths in the Black Sea basin

Due to the lack of information on the parameters of the described earthquake source, the tsunami generation simulation was carried out by setting the initial sea level shift in the elliptical region at zero velocity field. Initial displacement of the free sea surface centered at the point $\left(x_{0}, y_{0}\right)$, was set by the large and small axes $L$ and $W$ as the following distribution

$$
\zeta_{0}=a_{0} \cos ^{2}(\pi r / 2)(r \leq 1), \zeta_{0}=0(r>1),
$$

where $r=2 \sqrt{\left(x_{1} / L\right)^{2}+\left(y_{1} / W\right)^{2}}, x_{1}=\left(x-x_{0}\right) \cos \alpha+\left(y-y_{0}\right) \sin \alpha, y_{1}=\left(y-y_{0}\right) \cos \alpha-$ $-\left(x-x_{0}\right) \sin \alpha, \alpha$ is the inclination angle of the major ellipse axis to the $x$ axis, counted counter-clockwise. 
It is known that the tsunami source was quite extensive. The elliptical elevation parameters are taken from [14]. Thus, the maximum displacement of the sea surface in the earthquake region was assumed to be $a_{0}=1 \mathrm{~m}$, the major and minor axes of the ellipse are $L=65 \mathrm{~km}$ and $W=25 \mathrm{~km}$, respectively. The earthquake epicenter, according to the data of [5], was located on an underwater slope to the east of Yalta at a distance of $30 \mathrm{~km}$ and at a depth of approximately $1200 \mathrm{~m}$. The earthquake source coordinates were $44^{\circ} 31^{\prime} \mathrm{N}, 34^{\circ} 30^{\prime} \mathrm{E}$. The initial elevation is located so that the longitudinal axis of the ellipse is elongated along the isobath of $1200 \mathrm{~m}$.

To describe the process of tsunami wave propagation, a nonlinear twodimensional model of surface long waves taking quadratic bottom friction into account was used:

$$
\left\{\begin{array}{l}
\frac{\partial U}{\partial t}+\frac{\partial}{\partial x}\left(\frac{U^{2}}{D}\right)+\frac{\partial}{\partial y}\left(\frac{U V}{D}\right)=-g D \frac{\partial \zeta}{\partial x}-\frac{g k^{2}}{D^{7 / 3}} U \sqrt{U^{2}+V^{2}} \\
\frac{\partial V}{\partial t}+\frac{\partial}{\partial x}\left(\frac{U V}{D}\right)+\frac{\partial}{\partial y}\left(\frac{V^{2}}{D}\right)=-g D \frac{\partial \zeta}{\partial y}-\frac{g k^{2}}{D^{7 / 3}} V \sqrt{U^{2}+V^{2}} \\
\frac{\partial \zeta}{\partial t}+\frac{\partial U}{\partial x}+\frac{\partial V}{\partial y}=0
\end{array}\right.
$$

where $x, y$ are zonal and meridional coordinates; $t$ is time; $U(x, y, t)$ and $V(x, y, t)$ - the projections of the total liquid flow vector on $x$ and $y$ axes, respectively; $\zeta(x, y, t)$ is displacement of the free surface of the liquid from the horizontal position; $D=H(x, y)$ $+\zeta(x, y, t)$ is full (dynamic) depth of liquid, $H(x, y)$ is depth of the basin under unperturbed state of the liquid; $g$ is the free fall acceleration; $k=0.013 \mathrm{~s} / \mathrm{m}^{1 / 3}$ is the Manning roughness coefficient.

\section{Results of the numerical experiments}

In the first numerical experiment, the tsunami was simulated for the entire Black Sea on a grid with a spatial step of $500 \mathrm{~m}$. The integration time step was $1 \mathrm{~s}$, the calculations were carried out up to an isobath of $4 \mathrm{~m}$. At the solid coastal boundaries of the computational domain, the normal components of the total liquid flow were equated to zero.

The characteristic stages in the evolution of tsunami waves, obtained as a result of model calculations, are shown in Fig. 2. As can be seen, the ring wave, resulted from the initial elevation lowering, propagates unevenly due to the bottom relief inhomogeneities. When the waves approach the coast, their lengths decrease with the basin depth decreasing. The tsunami waves most rapidly reach the southern coast of Crimea, then the coast of Turkey, the Caucasian and Bulgarian coasts. And only 3 hours after the source action start the tsunami waves begin to appear on the north-western shelf.

In Fig. 3 (left) for 8 points of the Crimean and Caucasian coasts (Evpatoria, Sevastopol, Yalta, Feodosia, Kerch, Novorossiysk, Tuapse and Batumi) are the sea level fluctuations recorded by the mareographs during the earthquake of September 12, 1927 (data taken from [8, p. 273] and [14, p. 392]). The sea level fluctuations are clearly observed during the propagation of tsunami waves. The maximum heights of the recorded waves in these points did not exceed $0.5 \mathrm{~m}$. 

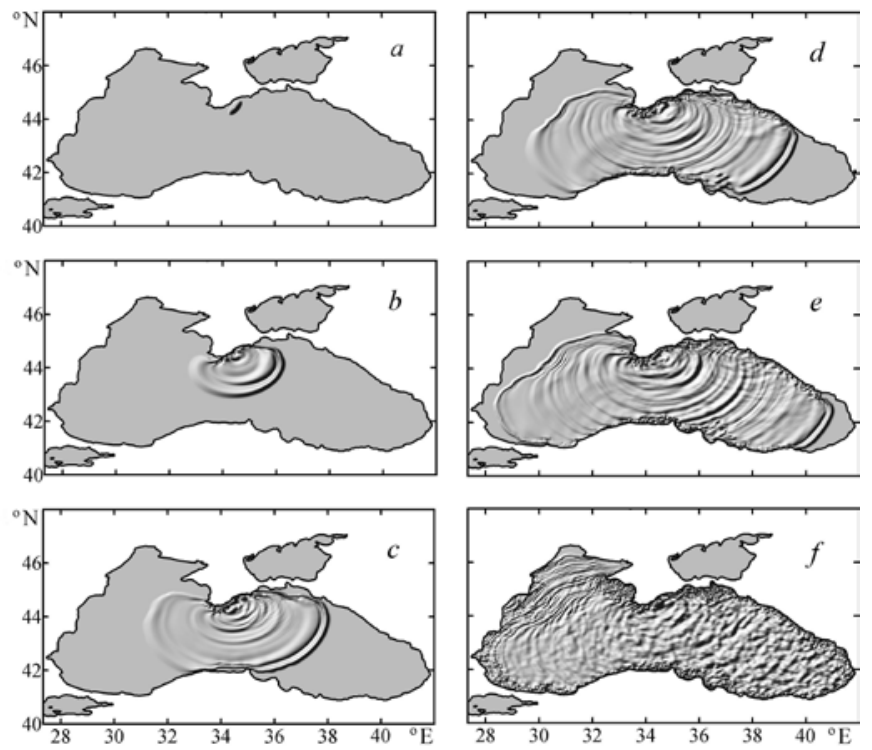

Fig. 2. Evolution of tsunami waves in the Black Sea propagating from the elliptical elevation induced by the earthquake of September 12, 1927: the wave field structure at the time moments $0(a), 15 \mathrm{~min}$. (b), 35 min. (c), 50 min. (d), 1 hr 10 min. (e), $3 \mathrm{hr}(f)$
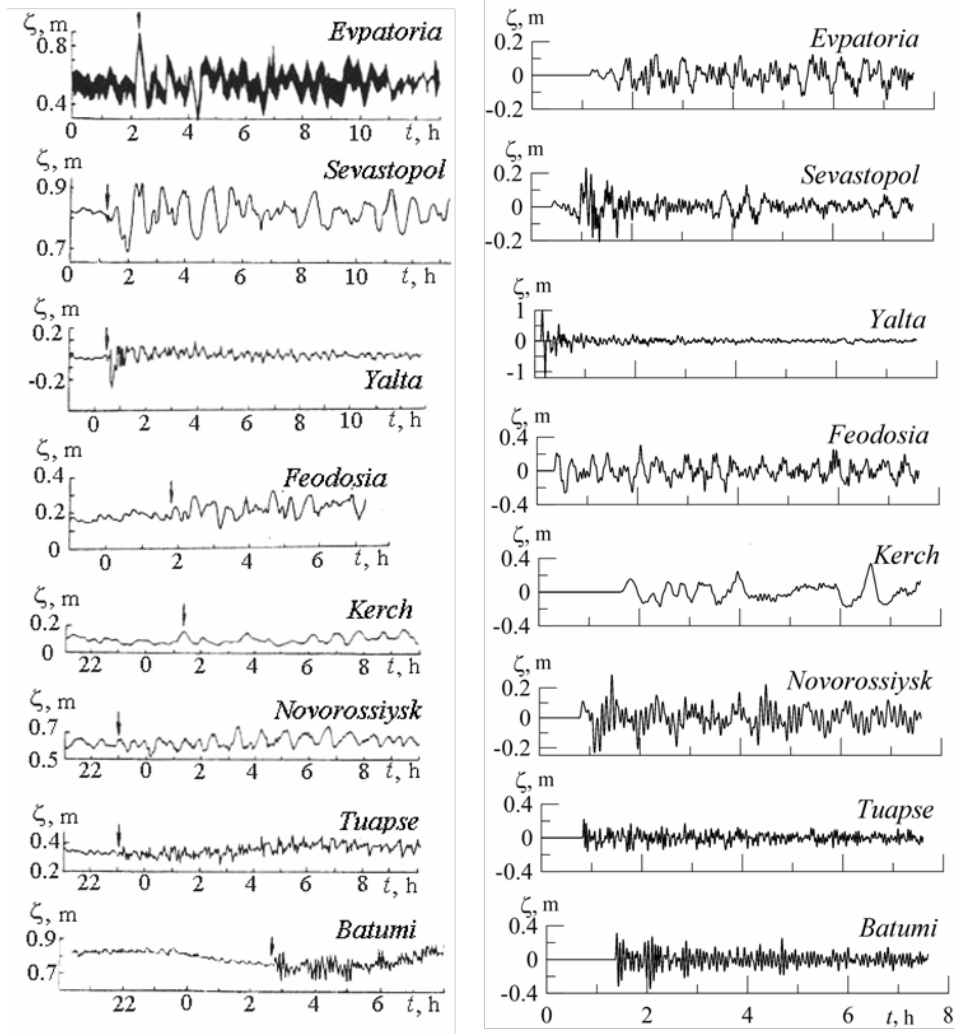

Fig. 3. Mareograms for some points of the Crimean and Caucasian coasts of the Black Sea during tsunami induced by the earthquake of September 12, 1927: to the left - the mareograph records [8, p. 273; 14, p. 392]; to the right - the sea level oscillations calculated within the framework of the model 
In Fig. 3 (right) the model mareograms are shown for the same items. The time of arrival of waves to the observation point is well observed. It is accompanied by an initial rise of the sea level at all points. It can be seen that the first wave is not always maximum. There is a qualitative similarity of the periods of fluctuations numerically calculated and instrumentally fixed. Their numerically obtained amplitudes at some points exceed those fixed by the mareographs. Discrepancy between the results obtained and the available measurements is due to the inability to simulate this event more accurately due to the small amount of information on the earthquake source parameters and amount and time of underwater shocks. In addition, the characteristics of tsunami waves in the coastal area can also be affected by local factors such as surge or seiche fluctuations.

According to the analysis of model mareograms, the most intense waves are observed at the basin point nearest to the tsunami source - in Yalta. The height of the waves here can reach $2 \mathrm{~m}$. In Evpatoria, the maximum wave height as a distance from the hollow to the crest was about $0.2 \mathrm{~m}$, in Sevastopol $-0.4 \mathrm{~m}$, in Feodosia $-0.5 \mathrm{~m}$, in Kerch $-0.4 \mathrm{~m}$, in Novorossiysk $-0.5 \mathrm{~m}$, in Tuapse $-0.3 \mathrm{~m}$, and in Batumi $-0.5 \mathrm{~m}$.

In the second numerical experiment, a detailed calculation of the tsunami evolution for the southern Crimean coast was carried out. This area is located most close to the earthquake source and is significantly more exposed to tsunami waves. The calculations were carried out on a grid with a spatial resolution of $50 \mathrm{~m}$ and a time step of $0.1 \mathrm{~s}$. To simulate the wave running up to the coast, the algorithm described in [19] was applied. The free passage condition for long waves was set at the liquid boundaries of the computational domain.

Fig. 4 shows the bathymetry and topography of the Southern coast of Crimea. Data on depths is taken from digitized large-scale navigational charts of the Azov-Black Sea basin. For the land relief description, data on the elevation of the Earth's surface from the Digital Terrain Elevation Data Level-1 array with a spatial step of 3" (URL: https://eros.usgs.gov/) was used.

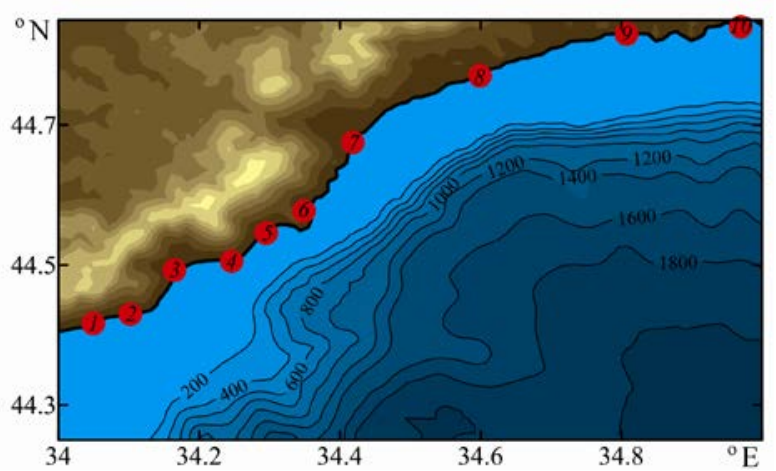

Fig. 4. Bathymetry of the Black Sea area in the region of the Crimea Southern coast. 1 - Alupka, 2 Gaspra, 3 - Yalta, 4 - Nikita, 5 - Gurzuf, 6 - Partenit, 7 - Alushta, 8 - Rybachie, 9 - Morskoe, 10 - Sudak

Calculation results of the tsunami wave formation from the elliptical initial sea level elevation are shown in Fig. 5. At the initial stage of the tsunami evolution, the central part of the initial elevation of the sea level drops, then the ring tsunami wave is formed (Fig. 5, b). The wave height is greatest in directions perpendicular to the longitudinal axis of the elliptical generation zone. When the waves approach the shore, their length decreases. In shallow waters, the wave heights elevation, their leading front becomes steeper due to a drop in the basin depth towards the coast. Then the process of 300

PHYSICAL OCEANOGRAPHY VOL. 25 ISS. 4 (2018) 
wave running up to the coast starts. It consists in alternating movement of the sea level upwards along the coast and retreating from it, either flooding or draining it. The time for the first wave to reach the nearest part of the coast is $\sim 5 \mathrm{~min}$.
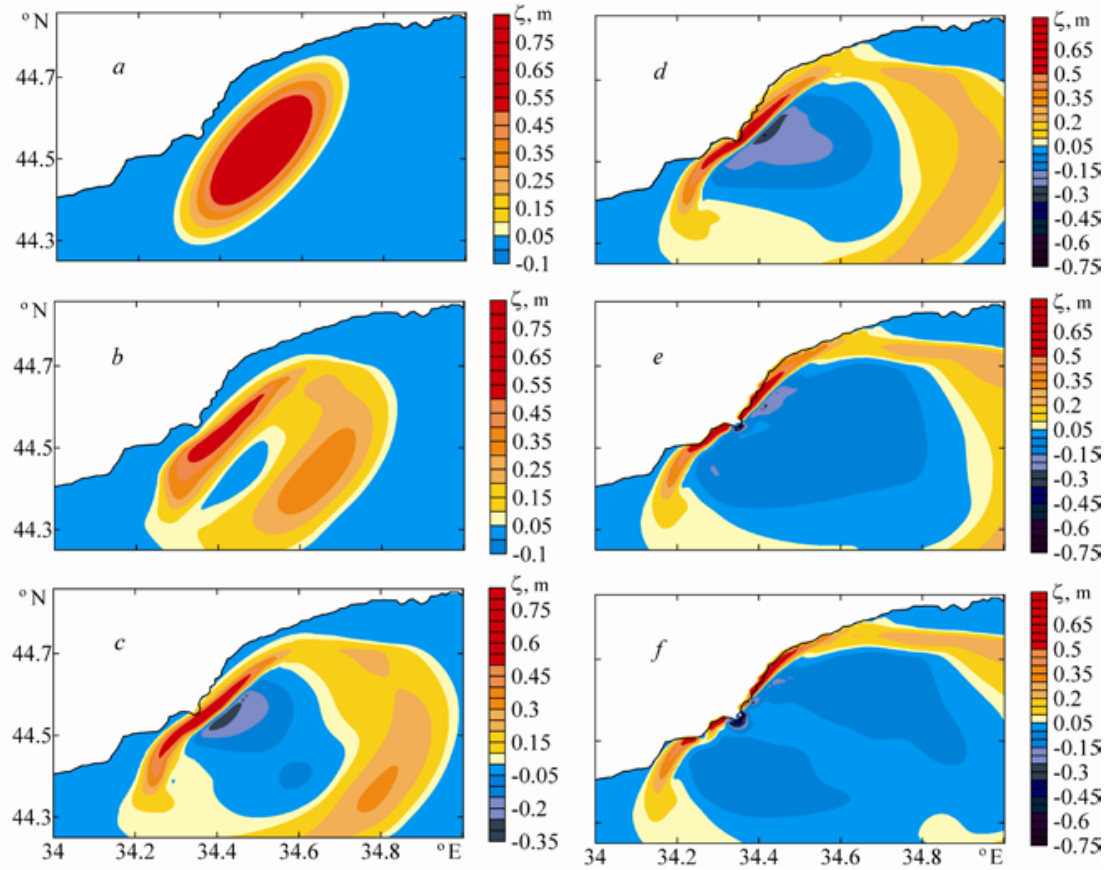

Fig. 5. The wave field structure at the tsunami wave propagation from the elliptical elevation induced by the earthquake of September 12, 1927 at the time moments 0 c (a), $100 \mathrm{c}(b), 200 \mathrm{c} \mathrm{(c),} 250 \mathrm{c}(d)$, $300 \mathrm{c}(e), 400 \mathrm{c}(f)$

Below the amplitude characteristics of tsunami waves in the studied section of the coast are considered. Fig. 6 shows the maximum elevations and drops of sea level when waves run up ashore for a number of points on the southern coast of Crimea. As can be seen, the level elevations can reach $2 \mathrm{~m}$ and in some points (Nikita, Gurzuf), the level drops in absolute value exceeding the running up height.

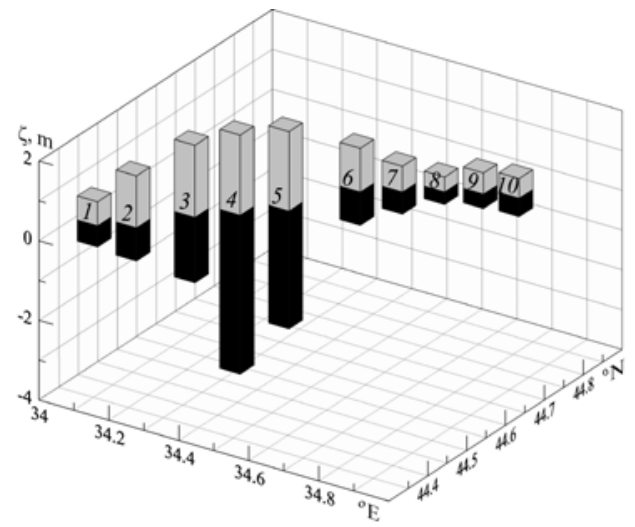

Fig. 6. Maximum sea level elevations and drops at the tsunami wave run-up on the coast induced by the earthquake of September 12, 1927 for the following inhabited localities of the Crimea Southern coast: 1 - Alupka, 2 - Gaspra, 3 - Yalta, 4 - Nikita, 5 - Gurzuf, 6 - Partenit, 7 - Alushta, 8 - Rybachye, 9-Morskoe, 10 - Sudak 

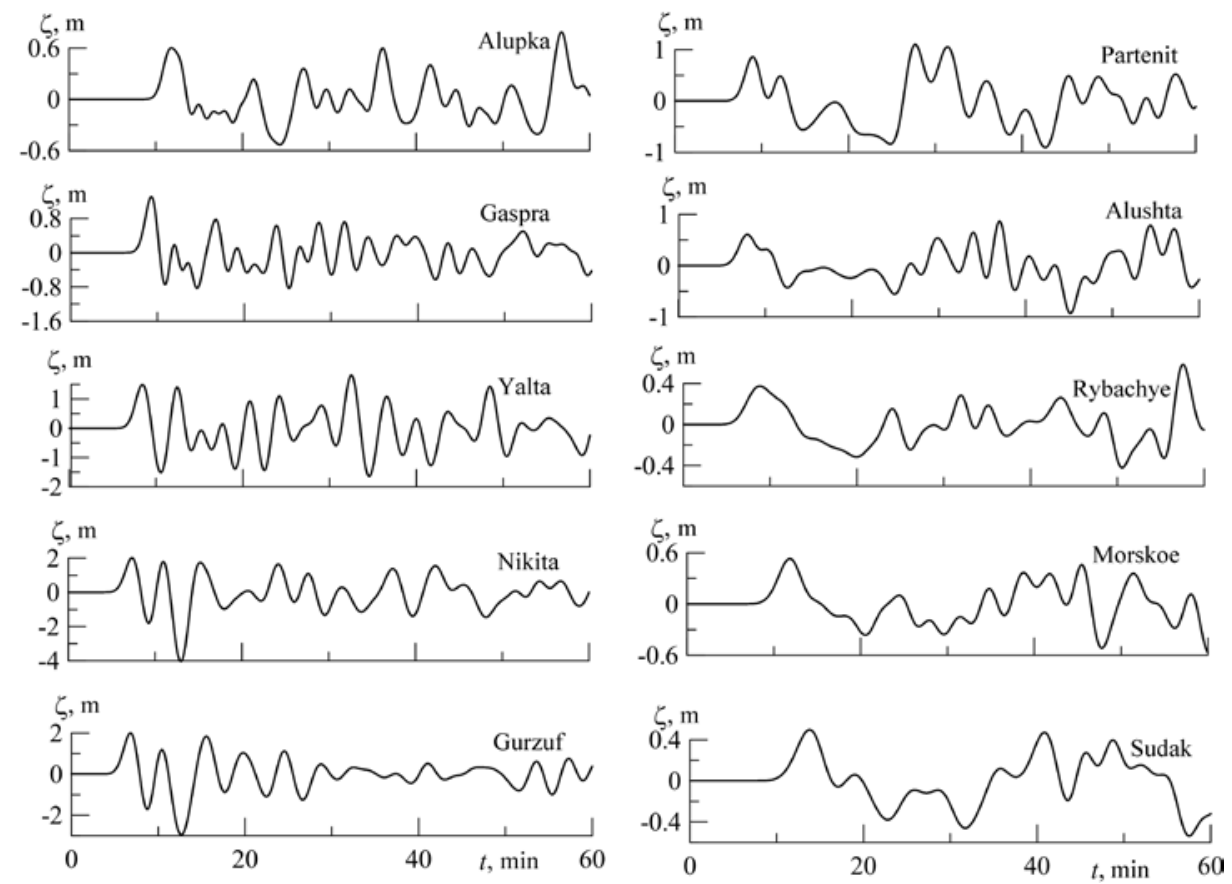

Fig. 7. The calculated mareograms for some points of the Crimea Southern coast at the tsunami wave propagation and run-up induced by the earthquake of September 12, 1927

In Fig. 7 model mareograms are shown for several points of the considered coast. It can be seen that the time of the wave run up to the coast at different points is from 5 to 10 minutes. Sea level fluctuations last a long time after the appearance of the first wave. The first wave is not always the maximum. Owing to the repeated reflection of waves from the coast, alternating elevations and drops of the level are observed. The maximum tsunami wave falls on the coastline from Gaspra to Alushta. Amplitudes of the wave fluctuations here reach 1-2 m. In Nikita, their amplitude is the highest, up to $6 \mathrm{~m}$ ( -4 to $2 \mathrm{~m}$ ). The minimum level fluctuations are observed in Alupka, Rybachye, Morskoye and Sudak and range from $-0.6 \ldots-0.4$ to $0.4 \ldots 0.6 \mathrm{~m}$.

\section{Conclusions}

The numerical simulation of the tsunami evolution in the Black Sea basin caused by the Yalta earthquake of September 12, 1927 was carried out. Local elevation of the level of the elliptical shape with time is transformed into a ring wave, which spreads throughout the sea. As a result, the tsunami wave approaches the coast as a flat alternating wave. Comparison of modeling results with data of records of the coastal mareographs is performed. The amplitudes of the model level oscillations in the coastal zone during propagation of tsunami waves are larger than those recorded instrumentally. The areas of the coast nearest to the tsunami generation source turned out to be the most susceptible to the effect of waves. The most intense waves, exceeding the sea level elevation in the source, take place in the region of Yalta. In other points, the level elevations do not exceed the initial elevation in the source. A more detailed calculation for the southern Crimean coast showed that the height of 
the tsunami run up can reach $2 \mathrm{~m}$, and the sea level drop at draining at some points is more than $3 \mathrm{~m}$.

\section{REFERENCES}

1. Nikonov, A.A., 1997. Tsunami Occurrence on the Coasts of the Black Sea and the Sea of Azov. Izvestiya, Physics of the Solid Earth, 33(1), pp. 77-87.

2. Nikonov, A.A., Gusiakov, V.K. and Fleifel, L.D., 2018. Assessment of the Tsunami Hazard on the Russian Coast Based on a New Catalogue of Tsunamis in the Black Sea and the Sea of Azov. Russian Geology and Geophysics, [e-journal] 59(2), pp. 193-205. doi:10.1016/j.rgg.2018.01.016

3. Dotsenko, S.F., 1995. The Black Sea Tsunamis. Atmospheric and Oceanic Physics. 30(4). pp. 483-489. Available at: http://eos.wdcb.ru/transl/izva/9404/pap12.ps [Accessed: 21 February 2018].

4. Dotsenko, S.F. and Ivanov, V.A., 2013. Katastroficheskie Prirodnye Yavleniya AzovoChernomorskogo Regiona [Catastrophic Natural Phenomena of the Azov-Black Sea Region]. Sevastopol: ECOSI-Gidrofizika, 193 p. (in Russian).

5. Grigorash, Z.K., 1959. Chernomorskie Tsunami 1927 Goda po Mareograficheskim Zapisyam [Black Sea Tsunami of 1927 by the Mareographic Records]. In: MHI, 1959. Trudy Morskogo Gidrofizicheskogo Instituta AN SSSR [Proceedings of MHI AS USSR]. Sevastopol: MHI. XVII, pp. 59-67 (in Russian).

6. Grigorash, Z.K., 1959. Rasprostranenie Tsunami 1927 v Chernom More [Tsunami Propagation of 1927 in the Black Sea]. In: MHI, 1959. Trudy Morskogo Gidrofizicheskogo Instituta [Proceedings of MHI AS USSR]. Sevastopol: MHI. XVIII, pp. 113-116 (in Russian).

7. Grigorash, Z.K. and Korneva, L.A., 1969. Volny Tsunami, Soprovojdavshie Anapskoe Zemletryasenie 12 iyulya 1966 g. [Tsunami Waves that Accompanied the Anapa Earthquake on July 12, 1966]. Oceanology, IX (6), pp. 988-995 (in Russian).

8. Grigorash, Z.K., 1972. Obzor Udalennyh Mareogramm Nekotoryh Tsunami v Chernom More [Review of Remote Mareograms of Some Tsunamis in the Black Sea]. In: SakhNIRO, 1972. Trudy Sahalinskogo Kompleksnogo nauchno-issledovatelskogo Instituta=Transactions of SakhNIRO. Yuzhno-Sakhalinsk: SakhNIRO. Iss. 29, pp. 271-278 (in Russian).

9. Pelinovsky, E., 1999. Preliminary Estimates of Tsunami Danger for the Northern Part of the Black Sea. Physics and Chemistry of the Earth, Part A: Solid Earth and Geodesy, [e-journal] 24(2), pp. 175-178. doi:10.1016/S1464-1895(99)00015-0

10. Yalçiner, A., Pelinovsky, E., Talipova, T., Kurkin, A., Kozelkov, A. and Zaitsev, A., 2004. Tsunamis in the Black Sea: Comparison of the Historical, Instrumental, and Numerical Data. Journal of Geophysical Research, [e-journal] 109(C12), C12023. doi:10.1029/2003JC002113

11. Dotsenko, S.F. and Ingerov, A.V., 2007. Characteristics of Tsunami Waves in the Black Sea according to the Data of Measurements. Physical Oceanography, [e-journal] 17(1), pp. 17-28. doi:10.1007/s11110-007-0002-z

12. Dotsenko, S.F. and Ingerov, A.V., 2009. Chislennye Otsenki Tsunamiopasnocti KrymskoKavkazskogo Poberejia Chernogo Morya [Numerical Estimates of the Tsunami Hazard along the Crimean-Caucasian Coast of the Black Sea]. Dopovidi NAN Ukrainy=Reports of the National Academy of Sciences of Ukraine, (6), pp. 119-125 (in Russian).

13. Zaitsev, A.I. and Pelinovsky, E.N., 2011. Forecasting of Tsunami Wave Heights at the Russian Coast of the Black Sea. Oceanology, [e-journal] 51(6), pp. 907-915. https://doi.org/10.1134/S0001437011050225

14. Dotsenko, S.F. and Konovalov, A.V., 1996. Tsunami Waves in the Black Sea in 1927: Observations and Numerical Modelling. Physical Oceanography, [e-journal] 7(6), pp. 389401. doi:10.1007/BF02509653

15. Oaie, G., Seghedi, A. and Rădulescu, V., 2016. Natural Marine Hazards in the Black Sea and the System of their Monitoring and Real-Time Warning. Geo-Eco-Marina, [e-journal] (22), pp. 5-28. http://doi.org/10.5281/zenodo.889593 
16. Papadopoulos, G.A., Diakogianni, G., Fokaefs, A. and Ranguelov, B., 2011. Tsunami Hazard in the Black Sea and the Azov Sea: a New Tsunami Catalogue. Natural Hazards and Earth System Sciences, [e-journal] 11(3), pp. 945-963. doi:10.5194/nhess-11-945-2011

17. Nikonov, A.A., 2002. Krymskie Zletryaseniya 1927 Goda: Neizvestnye Yavleniya na More [The Crimean Earthquakes of 1927: Unknown Phenomena at Sea]. Priroda, (9), pp. 13-20. Available at: http://www.ras.ru/FStorage/Download.aspx?id=b2912d23-8a1d-4180-be2b95e1f610dca1 [Accessed: 21 February 2018] (in Russian).

18. Shnyukov, E.F., Mitin, L.I. and Tsemko, V.P., 1994. Katastrofy $v$ Chernom More [Catastrophes in the Black Sea]. Kiev: Manuskript, 297 p. (in Russian).

19. Kowalik, Z. and Murty, T.S., 1993. Numerical Simulation of Two-Dimensional Tsunami Runup. Marine Geodesy, [e-journal] 16(2), pp. 87-100. doi:10.1080/15210609309379681

About authors:

Aleksandra Yu. Bazykina - Junior Research Associate, Department of Computational Technologies and Mathematical Modeling, FSBSI MHI (2 Kapitanskaya St., Sevastopol, Russian Federation, 299011), SPIN-code: 5633-9877, ORCID ID: 0000-0002-1299-0983, ResearcherID: M-6839-2018, aleksa.44.33@gmail.com

Sergey Yu. Mikhailichenko - Junior Research Associate, Department of Computational Technologies and Mathematical Modeling, FSBSI MHI (2 Kapitanskaya St., Sevastopol, Russian Federation, 299011), SPIN-code: 7351-9338, ORCID ID: 0000-0001-6332-1395, ResearcherID: M-5788-2018, liham1984@rambler.ru

Vladimir V. Fomin - Senior Research Associate, Department of Computational Technologies and Mathematical Modeling, FSBSI MHI (2 Kapitanskaya St., Sevastopol, Russian Federation, 299011), Dr.Sci. (Phys.-Math.), SPIN-code: 6992-2688, ORCID ID: 0000-0002-9070-4460, ResearcherID: H-8185-2015, v.fomin@ukr.net

Contribution of the co-authors:

Aleksandra Yu. Bazykina - scientific supervision, development and debugging of the computer program for solving the problem, analysis of the results, preparation of graphic materials, making conclusions, writing and editing of the article.

Sergey Yu. Mikhailichenko - digitization and creation of an array of elevations and depths for the embedded grid, discussion of the results, preparation of graphic materials, writing the summary.

Vladimir V. Fomin - the problem setting out and formulation, adaptation of the numerical algorithm to the physic-geographical conditions of the region under study, discussion of the results, editing the text of the article.

All the authors have read and approved the final manuscript.

The authors declare that they have no conflict of interest. 